rapidity and decision surpassing those of the Japanese. A conspicuous instance of this will be found in her recent action with respect to telegraphs. For years the Chinese steadily refused to have anything to do with them; the small land line which connected the foreign community of Shanghai with the outer world, was maintained against the violent protests of the local authorities, and the cable companies experienced some difficulty in getting permission to land their cables. But during the winter of $1879-80$, when war with Russia was threatening, the value of telegraphs was demonstrated to the Peking Government. The Peiho at Tientsin was closed by ice against steamers, and news could only be carried to the capital by overland couriers from Shanghai. Before a year elapsed a land line of telegraph was being constructed between this port and Tientsin ; in a few months the line was in working order, and the Chinese metropolis is now in telegraphic communication with every capital in Europe.

This conservatism, respect for antiquity, conceit, prejudice, call it what we will, has something in it that extorts our respect. Let us imagine a dignified and cultivated Chinese official conversing with a pushing Manchester or Birmingham man'ffacturer, who descants on the benefits of our modern inventions. He would probably commune with himself in this wise, whatever reply Oriental politeness would dictate to his interviewer: "China has got on very well for some tens of centuries without the curious things of which this foreigner speaks; she has produced in that time statesmen, poets, philosophers, soldiers; her people appear to have had their share of affliction, but not more than those of Europe ; why should we now turn around at the bidding of a handful of strangers who know little of us or our country, and make violent changes in our life and habits? A railway in a province will throw thousands of coolies and boatmen out of employment, and bring on them misery and starvation. This foreigner says that railways and telegraphs have been found beneficial in his country; good, let his countrymen have them if they please, but let us rest as we are for the present. Moreover, past events have not given us such faith in Europeans that we should take all they say for wisdom and justice." A day will undoubtedly come when China also will have her great mechanical and scientific enterprises; but what we contend for here is that nothing we can say or do will bring that time an hour nearer. European public opinion is to China a dead letter; she refuses to plead before that tribunal. Each step of her advance along our path must be the result of her own reflection and experience; and our wisest policy would be to leave her to herself to advance on it as she deems best. SINENSIS

\section{PROF. LINDSTRÖM ON OPERCULATE CORALS}

\section{$\mathrm{T}$}

$\mathrm{HE}$ extinct stony corals, the calicles of which are provided with calcareous opercula, have ever been a puzzle to naturalists, since they are almost entirely without parallel amongst existing Anthozoz. The genera and species are not numerous, and are all of Palæozoic age. By far the finest and best preserved specimens of the most important forms are found in the Silurian strata in the Island of Gothland in the Baltic, and are collected for the National Museum at Stockholm, where they come under the care of Prof. Lindström, the author of the present memoir, so justly distinguished for his palæontological researches generally, and especially for those on corals. In this memoir he gives a résumé of all the forms of operculate corals as yet known, embodying an immense amount of important new information derived from his own prolonged investigations on a series of most I “Om de Palæozoiska Formationernas Operkelbärande Koraller." Af
G. Lindström, Bihang till K. Svenska, Vet. Akad. Handlingar, B. 7, No. 4 . remarkable specimens which I had the advantage of seeing and having explained to me by him in the summer of last year. The whole paper forms a most valuable contribution to our knowledge of these especially interesting and peculiar corals.

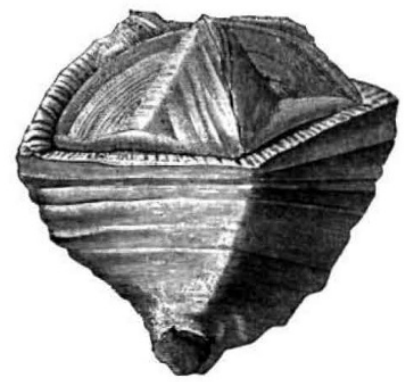

FIG. 1.-Goniophyllum pyramidale (mutatio secunda), viewed from above, with the opercular valves in situ of the natural size.

The first operculate coral described was Goniophyllum pyramidale, which Bromell in 1729 placed amongst the corals. The best known, and the one concerning which there has been the greatest difference of opinion, is Calceola sandalina, which was first figured in 1749 from the collection of Rosinus of Hamburg, by Brüchmann, who pointed out the resemblance of the coral to the front of a woman's slipper.

Brüchmann referred Calceola to the corals just as Bromell had Goniophyllum, but this was mainly because neither he or other early authors following him were acquainted with the opercula belonging to the specimens. Linné placed Calceola with the Mollusca as Anomia sandalina. Later it was referred to the Brachiopoda, a position in which a large number of eminent modern authorities retain it. If Calceola stood alone, the gravest doubts might certainly be entertained as to its having any relations to the corals; but now that a series of clearly allied forms such as Goniophyllum and Rhizophyllum, also bearing opercula, have had their structure so fully and satisfactorily worked out as has been done by Prof. Lindström, it is hardly possible not to follow him in placing the whole amongst the Anthozoa. The curious arrangement of the septa in Calceola closely resembles that in Goniophyllum as regards the septa both in the calicles and on the opercula. It is almost impossible to doubt the Anthozoan nature of Goniophyllum, whilst both it and Rhizophyllum, which has like Calceola an operculum of a single piece only, demonstrate their close relation to numerous recognised Palæozoic corals by exhibiting intracalicynal gemmation, and developing, like many other corals, abundance of roots.

The author divides the Anthozon operculata into two families -

I. Calceolidæ (or Heterotæchidæ), distinguished by having the septa on the inner face of the operculum not alike and a median septum the largest.

II. Aræopomatidæ (or Homotœchidæ), with the septa on the operculum all alike and no defined median septum.

The Calceolidæ include all those forms in which the operculum, whether composed of one or four valves, has this valve or valves marked inside with a stout prominent median septum.

The family falls into two groups-the one in which the operculum consists of a single valve containing three genera, namely, the well-known Calceola, distinguished by not multiplying by budding, being thus never compound, by having no root-tubes, and not showing vesicular structure internally; and two others-Rhizophyllum and Platyphyllum-in both of which calicynal gemmation occurs and the internal structure is vesicular, somewhat as in Cystiphyllum.

In Rhizophyllum, a genus founded by Lindström, the 
corallum is very much like that of Calceola in shape, but more elongated. It may be simple or form large masses by two modes of budding-either calicynal budding, or budding from the abundant rootlets. In the specimen of

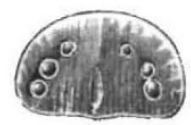

FIG. 2.-Rhizophyllum elongatum. View of the interior of the calic.e to show the six young calicles ceveloping as buds within it.

Rhizophyllum here figured, six young corals are seen in the act of developing as buds in the interior of the calicle.

In consequence of budding taking place from the "rootlets," the author advances the new suggestion that these bodies, the nature of which has always been doubtful, are to be regarded as stolons. The operculum of Rhizophyllum, by which the mouth of the calicle is completely closed, is, as in Calceola, of a semicircular shape, with a prominent ridge-like median septum on its inner face. In Rhizophyllum attenuatum, a compound form from Louisville, in Kentucky, first descrited by Mr. V. W. Lyon under the genus Calceola, the stolon tubes partly serve to connect together adjacent calicles, partly become themselves developed into fully-formed calicles. Specimens of Rhizophyllum Gothlandicum are found in abundance in the Island of Gothland with their opercula detached. The separate ofercula are also common. specimens with the opercula in situ are comparatively rare. A remarkably perfect one is shown in the accompanying figure.

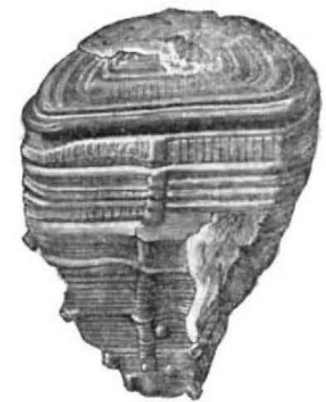

F1G. 3.- Rhizophyllum elongatum. View of the calicle with the operculum, a single valve only in situs.

The second group of the Calceolidx contains only a single genus-Goniophyllum-in which the mouth of the calicle is rectangular in form, and four opercular valves are present which, with their bases resting on the four sides of the mouth of the calicle, slope inwards to meet one another, and form a four-sided pyramidal roof over

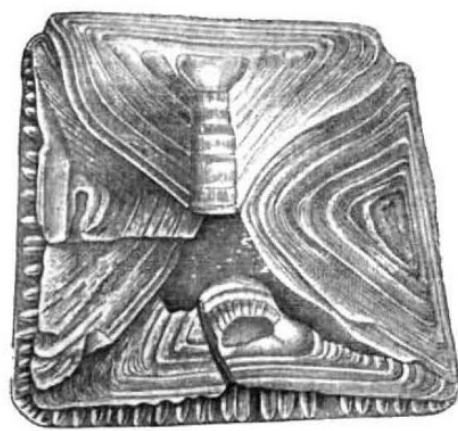

FIG. 4-Goniophyllum fyramiale (mutatio frima). View of the muth of the calicle, with the i fercular valves in situ, the dorsel right and left valves being entire, the ventral incomplete.

the calicle. From Gothland Prof. Lindström has been able to obtain two or three specimens with all the four opercular valves in situ. So that doubts as to the connection of the valves with the coral calicle are now inadmissible. On careful study of these specimens and numerous others with a fewer number of valves in situ, he finds that the four valves always present well-marked differences and form, and septal striation, so that it is possible to distinguish with certainty an anterior and posterior, or ventral and dorsal, and a right and left valve, and pick these out from any collection of well-preserved loose valves. The anterior and posterior valves are trapezoid in form, the lateral triangular. A most remarkable discovery he has made is that these corals must have shed their valves periodically, and replaced them, and that when shed the valves frequently happened to become attached to the wall of the calicle, and fused with it. In the accompanying figure of Goniophyllum pyramidale, seen from behind, a well-formed operculum is seen near the base firmly attached to the wall of the calicle near its base. Such

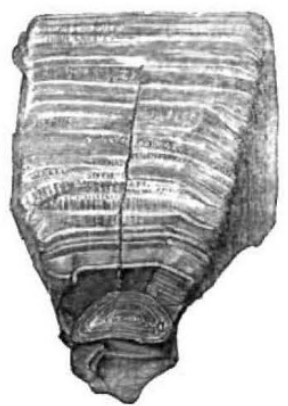

FIG. 5.-Goniophyllum pyramidale, viewed from the ventral side to show the shed opercular valve $(a)$ ccalesced with the wall of the calicle near its base.

specimens are not uncommon in Goniophyllum, but in another genus, a new one, Aræopoma, belonging to the second family of operculate coral, devoid of a median septum, and which has four triangular valves like Goniophyllum, very many specimens bear numerous valves fused to their outer walls, the valves being of increasing size from below upwards, in accordance with the growth and expansion of the coral and the mouth of its calicle. In one abnormal specimen of Goniophyllum pyramidale there are five opercular valves present, a minute extra triangular valve being interpolated at one of the corners.

Prof. Lindström, whose important researches on the development of the septa in so-called Rugose corals are familiar, has been able to trace the development of the corallum in Goniophyllum pyramidale. He finds that in the youngest stage of the calicle there is no septum present at all, then that one septum is formed on what may be termed the dorsal side of the calicle, and since in this genus and several others it remains conspicuously prominert, it may be termed the primary septum. Two further septa, the light and left median, are next formed, and last of all the ventral septum, long after the others. He points out that a similar process of development is followed in most Rugose corals, and that it is therefore erroneous to treat of four septa as primary in these forms.

In Rhytidophyllum shaped somewhat like Calceola, but belonging to the Aræopomatidæ, by reason of the absence of a defined median septum on the oferculum there is only a single opercular valve. A further genus of the group is possibly represented by a single broken operculum, of which further sfecimens have not yet been found.

In connection with the operculate corals, Prof. Lindström describes certain coral forms in which remarkable exothecal structures are present, which may be considered as more or less homologous with opercular valves. In Pholidophyllum tubulatum, a compound coral, first described as Tubiporites tutulatus by Schlotteim in 1813 , 
and which has lately been made a subject of research by $G$. von Koch, the costæ are in solitary specimens clad each with a longitudinal rib composed of a dcuble row of rhomboidal calcareous scales placed close together at an angle to one another as shown in the figure. These rows of scales form an almost complete outer covering to the corallum. The scales seem to be wanting in colonial specimens. They are extremely conspicuous and definite in some of the best preserved solitary specimens, and their regularity of disposition is such that it is impossible to believe that they do not definitely belong to the coral. They are shown enlarged in the figure. In vertical sec-

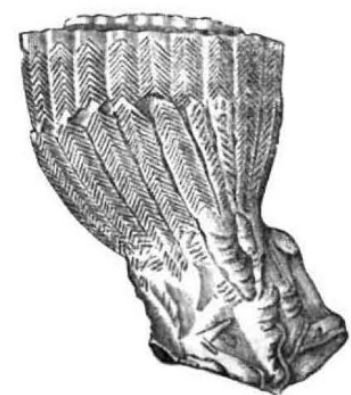

FIG. 6.-Pholidophyllum mbulatum. A calicle viewed from the side to show the rib-like prominences formed upcn the costæ by the double rows of calcarecus scales.

tions of the coral they are seen to be attached at their bases to the wall of the calicle. In Syringophyllum organum similar scales occur covering the exterior of the corallum, but these have a remarkable definite form somewhat like that of the bowl of a teaspoon with the handle cut off short.

As an illustration of the possibility of Anthozoa bearing opercula and scales, but not as implying any direct relationship between the Operculata and the Alcyonaria, Prof. Lindström points to the structure of Primnoa lepadifera, and figures one of the polyps viewed from above, showing how eight of the valve-like calcareous scales present in this species close in over the summit of the polyp, forming a conical operculum over it somewhat as in Goniophyllum, whilst the remaining scales form a representative of the calicle. He shows that, as in Goniophyllum, the opercular valves differ in form and size according to their position when in situ.

In his concluding paragraph he states that he considers the Calceolidæ to be probably nearly allied to such forms as Cmphyma and Chonophyllum, whilst the Aræopomatidæ, on account of their vesicular internal structure, approach more nearly to Cystiphyllum. He does not consider the presence or absence of an operculum in corals to be necessarily of an important classificatory value, and cites the case of the presence and absence of opercula in Gastropoda as a parallel one of minor systematic importance. In this it is rather difficult to agree with bim. Of course the opercula in Gastropods ard corals are alike only in name, and as they occur so rarely in the latter the suspicion naturally arises that the two groups of the operculate corals may be more closely allied than he suspects. However, no man knows them better than he, or has a better right to an opinion on the subject, and his conclusion, guarded as it is, must be treated with all respect.

A very interesting result attained and given in tabular form on p. 91 is that in successive Upper Silurian strata a series of three modifications of form of Goniophyllum pyramidale, starting from Goniophyllum pyramidale, primigena, the form occurring in the lowest beds can be traced succeeding cne another in time. Similarly Rhizophyllum Gothlandicum, forma primaria passes by a modification, R. G. mutalia, into R. Gervillei, of specific rank in the Devonian formations. Other oferculate corals show similar modifications in progress of geological time. Prof. Lindström's important memoir cannot here be followed farther. It is illustrated by nine lithographic plates most beautifully executed in Stockholm, from which the engravings here given are copied, and are some of the most excellent ever published of corals.

\section{H. N. Moseley}

\section{BARON NORDENSKJÖLD'S EXPEDITION TO GREENLAND}

[THE following Programme, drawn up by Baron Nordenskjöld for his expedition to Greenland, has been kindly placed at our disposal by Mr. Oscar Dickson, who, with his well-known enlightened liberality, provides all the expenses. The Programme has not hitherto been made public, even in Sweden, as Baron Nordenskjöld did not wish to be interrupted in his preparations with correspondence on his plans and theories. The expedition leaves Sweden in the Sofia on the 2oth instant, and will call at Thurso, where Baron Nordenskjöld will join the vessel.]

NinE centuries have elapsed since the Norwegian, Erik Röde, discovered Greenland, and founded Scandinavian Colonies; from these, Norwegian navigators some ten years after sailed south to "Vinland," the fecundus, i.e. to the shores of the present Canada and the United States, thereby acquiring the honour for the Norse race of being the real discoverers of the New World. It is not known whether these voyages led to any fixed settlements being established in America, but we know, on the other hand, from a number of Icelandic sources, that the colonies in Greenland became very flourishing. There were upwards of three hundred farms, "Gaarde," of which about two hundred, embracing twelve parishes, were situated in the "Österbygd," and about one hundred, embracing three or four parishes, were situated in the "Vesterbygd." During four centuries the country formed a bishopric, from which funds towards the Holy Wars were even contributed. Unfortunately, the connection between the colonies and the mother country ceased after a couple of centuries, while Greenland's ancient Norse population was extirpated, either through plagues or by "Skrællings," i.e., the Eskimo who descended from the North. Another explanation of their disappearance is that they lost their nationality, and were absorbed into the Eskimo population, during their contact with the more numerous tribes of the Polar regions, whose mode of living was more suited to the climate of the country and the resources at their disposal. However that may be, there remains the fact that one of the most distinct and enterprising peoples in the world have been annihilated, or, perhaps, absorbed in one distinguished as among the lowest, both physically and intellectually. The old country, belonging to the Norwegian Crown, was even so far forgotten, that it was only Columbus's discovery in the south which recalled the attention of the Norsemen to the fact that they had once colonised a part of this world, which was being parcelled out among the southern nations by "Bulls" from Rome, as if it had just been discovered.

By the aid of traditions and old journals of navigation several attempts were made to reach the old, forgotten colonies from Iceland, but these were frustrated by the enormous masses of drift ice, which then seemed to inclose the shores of Greenland's east coast, more than formerly. Eventually, John Davis, in his attempts to find the north-west passage, discovered that the west coast was easily reached, and that the seas around it offered a fine hunting-ground for the profitable whalefisheries. This, with the reported discovery of gold in the country resulted in the despatch of several Danish hunting and commercial expeditions, which did not, however, meet with much success, until the Norwegian, 